University of Nebraska - Lincoln

DigitalCommons@University of Nebraska - Lincoln

Spatial dynamics of overbank sedimentation in floodplain systems

\author{
Aaron R. Pierce \\ University of Tennessee, aaron.pierce@nicholls.edu \\ Sammy L. King \\ USGS Louisiana Cooperative Fish and Wildlife Research Unit, sking16@lsu.edu
}

Follow this and additional works at: https://digitalcommons.unl.edu/usgsstaffpub

Pierce, Aaron R. and King, Sammy L., "Spatial dynamics of overbank sedimentation in floodplain systems" (2008). USGS Staff -- Published Research. 559.

https://digitalcommons.unl.edu/usgsstaffpub/559

This Article is brought to you for free and open access by the US Geological Survey at DigitalCommons@University of Nebraska - Lincoln. It has been accepted for inclusion in USGS Staff -- Published Research by an authorized administrator of DigitalCommons@University of Nebraska - Lincoln. 


\title{
Spatial dynamics of overbank sedimentation in floodplain systems
}

\author{
Aaron R. Pierce ${ }^{a, *}$, Sammy L. King ${ }^{b}$ \\ ${ }^{a}$ Department of Forestry, Wildlife, and Fisheries, University of Tennessee, Knoxville, TN 37996, USA \\ ${ }^{\mathrm{b}}$ USGS Louisiana Cooperative Fish and Wildlife Research Unit, LSU AgCenter, 124 School of Renewable Natural Resources, Baton Rouge, LA 70803, USA
}

Received 26 July 2007; received in revised form 20 December 2007; accepted 26 December 2007

Available online 12 January 2008

\begin{abstract}
Floodplains provide valuable social and ecological functions, and understanding the rates and patterns of overbank sedimentation is critical for river basin management and rehabilitation. Channelization of alluvial systems throughout the world has altered hydrological and sedimentation processes within floodplain ecosystems. In the loess belt region of the Lower Mississippi Alluvial Valley of the United States, channelization, the geology of the region, and past land-use practices have resulted in the formation of dozens of valley plugs in stream channels and the formation of shoals at the confluence of stream systems. Valley plugs completely block stream channels with sediment and debris and can result in greater deposition rates on floodplain surfaces. Presently, however, information is lacking on the rates and variability of overbank sedimentation associated with valley plugs and shoals.

We quantified deposition rates and textures in floodplains along channelized streams that contained valley plugs and shoals, in addition to floodplains occurring along an unchannelized stream, to improve our understanding of overbank sedimentation associated with channelized streams. Feldspar clay marker horizons and marker poles were used to measure floodplain deposition from 2002 to 2005 and data were analyzed with geospatial statistics to determine the spatial dynamics of sedimentation within the floodplains.

Mean sediment deposition rates ranged from 0.09 to $0.67 \mathrm{~cm} / \mathrm{y}$ at unchannelized sites, 0.16 to $2.27 \mathrm{~cm} / \mathrm{y}$ at shoal sites, and 3.44 to $6.20 \mathrm{~cm} / \mathrm{y}$ at valley plug sites. Valley plug sites had greater rates of deposition, and the deposited sediments contained more coarse sand material than either shoal or unchannelized sites. A total of 59 of 183 valley plug study plots had mean deposition rates $>5 \mathrm{~cm} / \mathrm{y}$. The geospatial analyses showed that the spatial dynamics of sedimentation can be influenced by the formation of valley plugs and shoals on channelized streams; however, responses can vary. Restoration efforts in the region need to have basinwide collaboration with landowners and address catchment-scale processes, including the geomorphic instability of the region, to be successful.
\end{abstract}

(C) 2008 Elsevier B.V. All rights reserved.

Keywords: Channelization; Floodplain; Geomorphology; Sedimentation; Shoals; Valley plugs

\section{Introduction}

Floodplains have received considerable attention in recent years because of the valuable social and ecological functions of these systems, such as flood control, sediment and nutrient retention, recreational opportunities, timber production, and wildlife habitat. Contemporary floodplain sedimentation rates have been the focus of much attention because of their role in river basin management and their ecological significance

\footnotetext{
* Corresponding author. Present address: Department of Biological Sciences, Nicholls State University, Thibodaux, LA 70310, USA. Tel.: +1 985493 2628; fax: +1 9854932496 .

E-mail address: aaron.pierce@nicholls.edu (A.R. Pierce).
}

in determining the composition and structure of vegetation communities and overall biodiversity of floodplain systems (Hodges, 1997; Walling and He, 1998; Hupp, 2000; Ward and Trockner, 2001).

Within-channel and overbank depositions are the primary processes of floodplain development (Knighton, 1998; Walling and He, 1998). During overbank flows, sediment can be deposited on the floodplain by different mechanisms based on the quantity and texture of the sediment resulting in generalized spatial patterns of deposition (Pizzuto, 1987; Knighton, 1998; Middelkoop and Asselman, 1998; Middelkoop and Van Der Perk, 1998; Nicholas and Walling, 1998; Walling and He, 1998). The greatest deposition, consisting of heavier and coarser particles, occurs near the channel as bedload material is transported 
by traction from the main channel to the floodplain. Floodplain sites farther away from the channel, that retain slow-moving or stagnant water, allow fine sediments such as silt and clay particles to settle out of the water column.

Variations in the quantity and quality of sediment stored in the floodplain are a result of local factors, such as frequency and magnitude of floods, distance to the channel, sediment load, sediment texture, water velocity, floodplain morphology, and vegetation cover (Knighton, 1998; Hupp, 2000). Basin level factors (such as position within the fluvial system, climatic variations, and land use) can also influence overbank deposition (Steiger et al., 2003). The dynamic nature of these alluvial systems enables sediment deposited in floodplains to be reworked over time and potentially create future river management problems (Walling and He, 1998). Therefore, depositional areas and the processes associated with them vary both spatially and temporally.

Throughout the southeastern Coastal Plain of the U.S., channelization has severely affected fluvial-geomorphic processes at multiple spatial and temporal scales (Schumm et al., 1984; Simon and Hupp, 1987; Simon, 1989; Shankman, 1993, 1996). The increased stream power of channelized streams typically increases the quantity and coarseness of the sediment load (USDA, 1970; Simon, 1994; Hopkinson and Vallino, 1995). In the upper reaches of a channelized system, channel bank failure and sediment transport typically occur. In contrast, lower reaches tend to accumulate large amounts of sediment because decreased stream gradients and channel obstructions (such as debris jams), and slow water velocities cause deposition of the increased sediment load (Schumm et al., 1984; Simon and Hupp, 1987; Wyzga, 2001). Aggradation of sediment in the lower reaches can cause a filling in and widening of the channel, which has been identified as a recovery process of channelization (Schumm et al., 1984; Simon and Hupp, 1987; Bravard et al., 1997). However, increases in deposition rates in these lower reaches can also disrupt functional processes of wetland systems (Happ et al., 1940; Schumm et al., 1984; Simon and Hupp, 1992; Brierley and Murn, 1997; Fryirs and Brierley, 1998; Brooks and Brierley, 2000, 2004).

In western Tennessee, Kentucky, and Mississippi, USA, the geology of the region and land-use practices have exacerbated the effects of channelization on fluvial-geomorphic processes. Past agricultural practices have led to erosion of the region's thin loess cap and have exposed and eroded the coarse alluvial sands that lie beneath the loess cap, resulting in massive gully erosion (Happ et al., 1940; Hupp, 1992; Saucier, 1994; Bettis et al., 2003). In western Tennessee, erosion over the past 150 years is estimated to be equal to the erosion that occurred during the previous several thousand years (Saucier, 1994). Historically, the high meandering rate and low gradient of the rivers did not allow for transport of the sand. However, channelization of all rivers in western Tennessee, except the main stem of the Hatchie River, has greatly increased their stream power and led to dramatic geomorphic changes (Diehl, 2000; Oswalt, 2003), including the formation of over 30 valley plugs and shoals in the Hatchie River watershed (Diehl, 2000).

Valley plugs (Fig. 1A) are areas where the entire channel becomes filled to at or above bank elevation with sediment, forcing floodwater and sand bedload out into the floodplain (Happ, 1975). Valley plugs typically form in the lower reaches of systems, where debris jams form or where the stream gradient decreases causing deposition of sediment (Happ et al., 1940). At valley plugs, sediment is spread across the floodplain as the stream splits from the main channel forming anastomosing streams throughout the floodplain (Happ et al., 1940; Diehl, 2000) (Fig. 2A, B). Currently, little information is available on the timescale involved in valley plug formation or their processes of development. The plugs in the Hatchie River watershed are thought to have formed in the 1970s when most of the tributaries were channelized (Pierce and King, 2007). Valley plugs may expand upstream as new sediments are delivered to the plug, but the rates of expansion may be extremely variable (Happ et al., 1940; Pierce 2005). Field observations suggest that distributaries that form near the head of the plug are also unstable and may be reworked or abandoned as the plug evolves (Fig. 2C). However, distributaries that do persist can create a new channel that diverts flows around the plug. In these cases, multiple plugs are typically located over the channelized reach of the stream. Channel filling, sand splays, and vertical accretion are all thought to be associated with valley plugs in much greater quantities than in unaltered systems (Happ et al., 1940). However, the rates and variability of accretion processes associated with valley plugs have not previously been investigated or quantified.
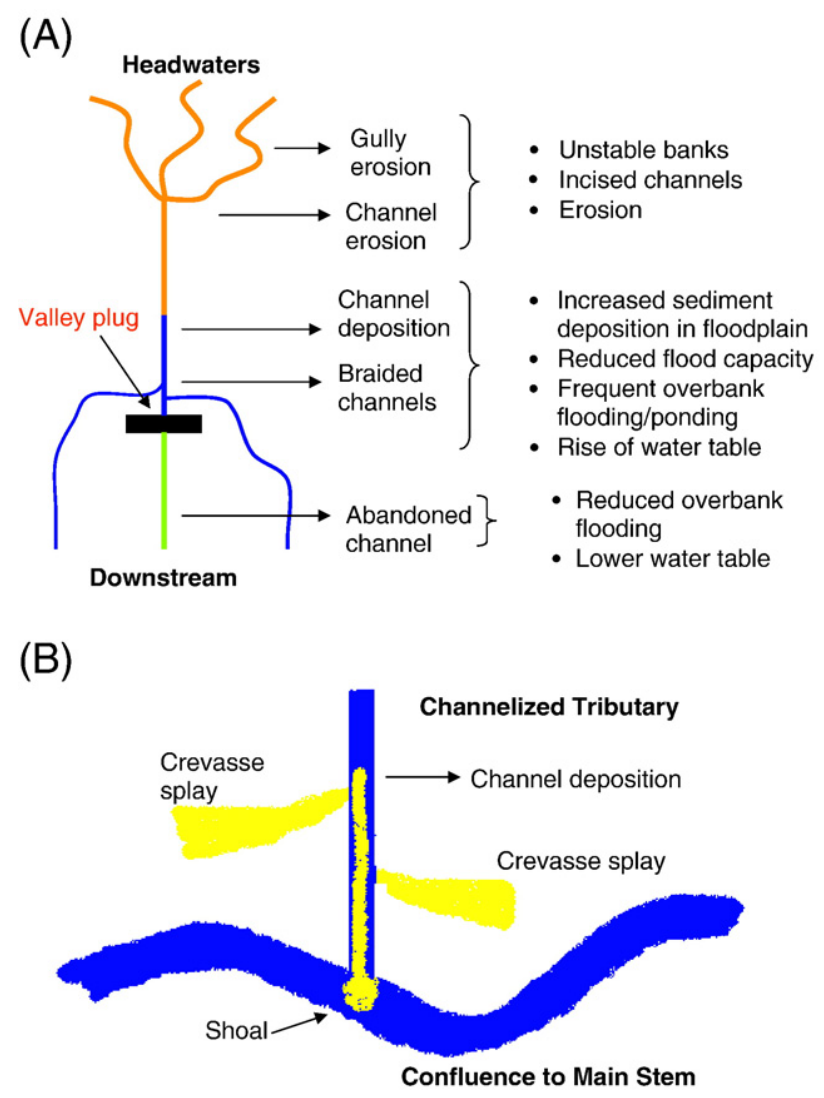

Fig. 1. Illustrates the possible processes and impacts of the presence of (A) a valley plug and (B) a shoal within a channelized stream system. 
(A)

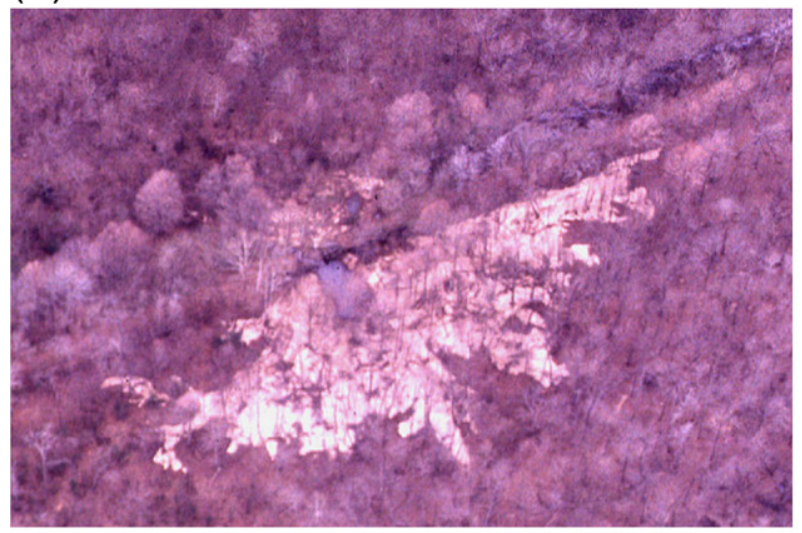

(B)

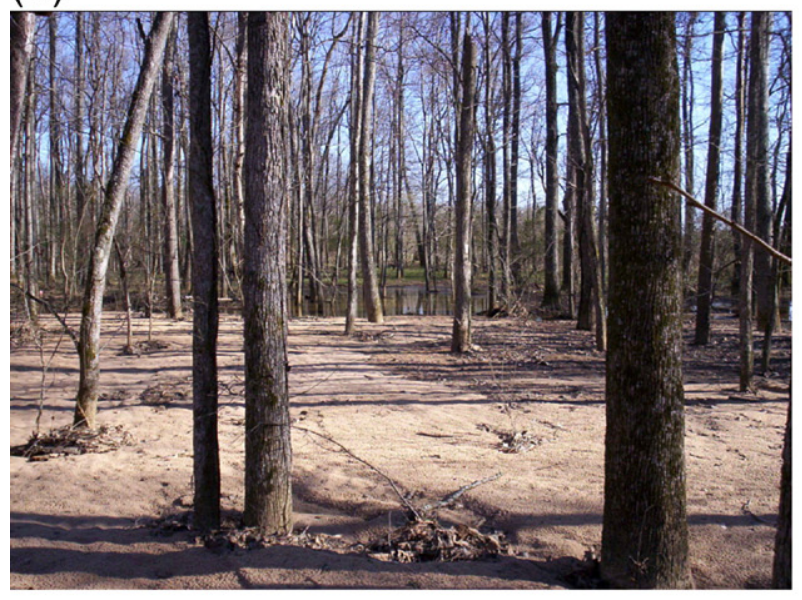

(C)

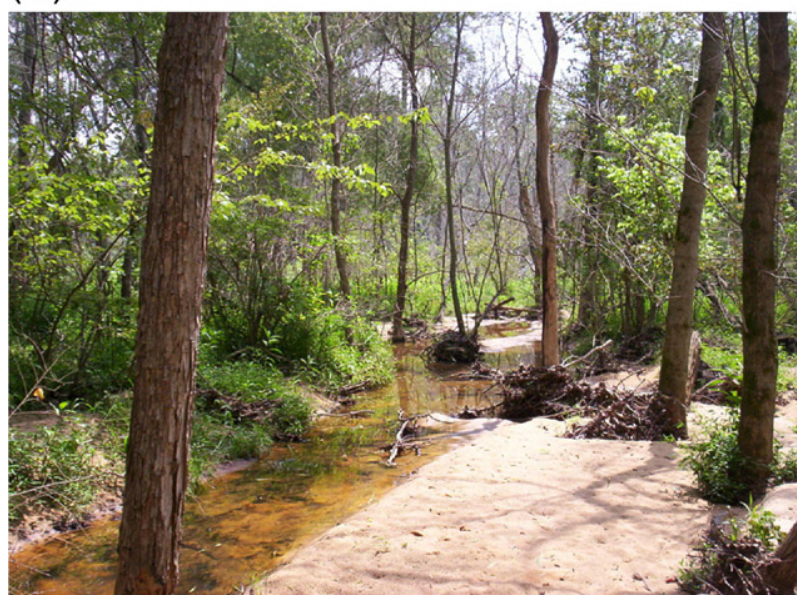

Fig. 2. (A) Aerial view of a large sand splay that has deposited in the floodplain as a result of valley plug formation, (B) greater deposition rates of coarse sand bury trees in floodplains affected by valley plugs and cause ponded areas within the floodplain, and (C) example of a distributary that has formed as a result of a valley plug.

Shoals (Fig. 1B), which are points in the channel where the depth decreases downstream from bedload deposition, usually form at the confluence of tributaries with the main stem of the river (Diehl, 2000). Shoal sites may be impacted in similar ways as valley plug sites, but even less is known about the sedimentation processes associated with shoals. Because the stream channel at shoal sites is not completely blocked with sediment, less sediment deposition in the floodplain adjacent to shoal sites may be expected. However, some areas corresponding to overflow channels and crevasse splays upstream of shoals may experience high deposition rates. During high flow events, shoals may force flood waters into the floodplain, with high velocity flows occurring in isolated areas of the floodplain where the difference in elevation between the channel and floodplain is lowest. The high velocity flows carry stream bedload into isolated areas of the floodplain, where the flows slow and deposit large amounts of sediment, causing a crevasse splay effect (Knighton, 1998).

The processes discussed above are consistent with the valley plugs and shoals located within the Hatchie River watershed (Diehl, 2000) and throughout the loess belt region of Kentucky, Tennessee, and Mississippi (Happ et al., 1940). Because of channelization of the tributaries of the Hatchie River, the main channel has become shallower and flooding has increased (USDA, 1986). The formation of valley plugs and shoals in numerous channelized tributaries (Diehl, 2000) may result in degraded aquatic habitats, reduced flood storage capacity of the stream, accelerated development of natural levees, increased inundation of the floodplain, and burial of fertile soils with infertile sand and gravel (Happ et al., 1940). Although several organizations are interested in the restoration of the Hatchie River tributaries, efforts are hampered by a poor understanding of the sedimentation dynamics in these altered systems.

The first objective of this study was to determine differences in sediment deposition rates and texture of deposited sediments in floodplain forests adjacent to three different features: unchannelized streams, shoals, and valley plugs. The second objective was to use geospatial statistics to determine and compare the direction and degree of spatial continuity of deposition rates at one unchannelized site, two shoal sites, and three valley plug sites. If deposition was occurring as classical fluvial geomorphology theory would predict, then we would expect a high degree of spatial correlation among deposition rates across the floodplain, and the direction of spatial dependence should be parallel with the stream flow.

\section{Regional setting}

The Hatchie River originates in the Upper East Gulf Coastal Plain of Mississippi flowing NW into Tennessee until draining into the Mississippi River north of Memphis. The Hatchie River drainage area is $\sim 177 \mathrm{~km}$ long and averages $39 \mathrm{~km}$ wide to include over 673,654 ha, $72 \%$ of which are located in Tennessee (USDA, 1986). Our study area is located in Haywood, Madison, and Hardeman Counties in Tennessee, stretching south from the Hatchie National Wildlife Refuge in Brownsville to Hickory Valley. We selected six tributaries of the Hatchie River for intensive study (Fig. 3). We established three unchannelized sites along Spring Creek (Table 1), with the first site located at the confluence of Spring Creek and the Hatchie River and the two upstream sites at a minimum distance of $2 \mathrm{~km}$ between each site. Spring Creek is a natural meandering tributary of the Hatchie River and contains extensive floodplain forests. Spring 


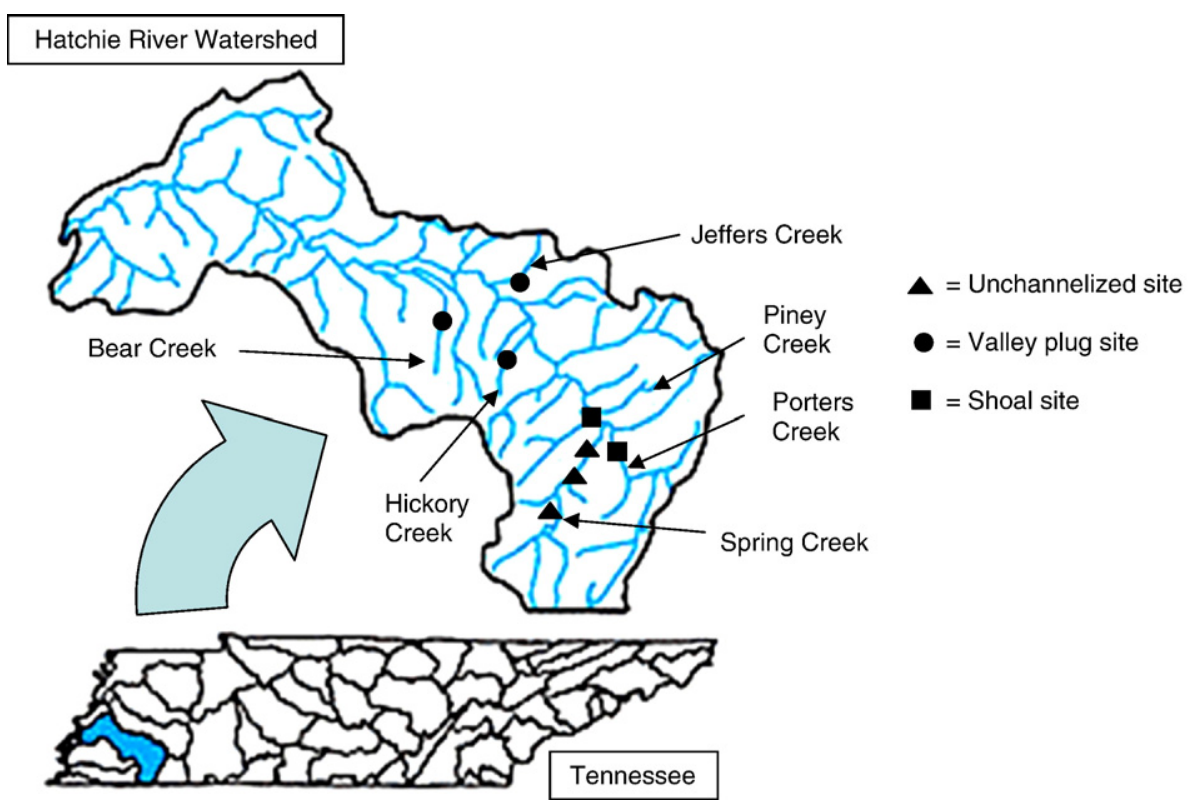

Fig. 3. Location of the Hatchie River Watershed and spatial distribution of study sites along selected tributaries of the Hatchie River.

Creek is the only unaltered tributary within our $\sim 50 \mathrm{~km}$ study segment of the Hatchie River (USDA, 1986). The forest at Spring Creek was dominated by baldcypress (Taxodium distichum (L.) Rich.), water tupelo (Nyssa aquatica L.), sweetgum (Liquidambar styriciflua L.), river birch (Betula nigra L.), water oak (Quercus nigra L.), and overcup oak (Q. lyrata Walt.) (Pierce, 2005). The three valley plug sites were on the channelized tributaries of Bear Creek, Jeffers Creek, and Hickory Creek (Table 1). Although the exact dates of channelization of these streams are unknown, most of the Hatchie River tributaries were channelized by the 1970s (Simon and Hupp, 1992; Simon, 1994). By 1971, the completed channelization projects had directly and indirectly reduced the bottomland hardwood habitat along the affected reaches, including our study sites, by 60\% (Barstow, 1971; Turner et al., 1981). Channelized valley plug sites were all within $5 \mathrm{~km}$ of their respective tributaries' confluence with the Hatchie River. Some private landowners may dredge the channel at the locations of valley plugs, which allows sediment to be deposited downstream of the plugs. Although this may be common within the western Tennessee region, we are only aware of this occurring at the Jeffers Creek valley plug site approximately two years before this study was initiated. The forest composition and structure were similar at all three channelized valley plug sites; boxelder (Acer negundo L.), green ash (Fraxinus pennsylvanica Marsh.), black willow (Salix nigra Marsh.), river birch, sycamore (Platanus occidentalis L.), red maple (A. rubrum L.), and sweetgum were the dominant species (Pierce, 2005). The two shoal sites were located at the confluence of the Hatchie River and the channelized Porters Creek and Piney Creek (Table 1); each contained shoals at their confluence with the Hatchie River. The forest composition and structure at both shoal sites were similar to that of the unchannelized sites (Pierce, 2005). Although forest composition differed among site types, stem density and basal area were similar (Pierce, 2005, Pierce and King, 2007). No hydrologic data were available for any of the tributaries.

\section{Materials and methods}

\subsection{Deposition rates}

Sediment deposition rates were measured once a year for three years, during the fall low-water period, from 2002 to 2005

Table 1

Study sites with identification of site type, the total stream length, stream width at study site, percent of channelization, upstream basin size at the study site, total basin size of the tributary, and effective floodplain width (flood prone width of the floodplain) at the study site

\begin{tabular}{|c|c|c|c|c|c|c|c|}
\hline Site & Site type & $\begin{array}{l}\text { Stream length } \\
(\mathrm{km})\end{array}$ & $\begin{array}{l}\text { Stream width } \\
\text { (m) }\end{array}$ & Percent channelized & $\begin{array}{l}\text { Upstream basin } \\
\left(\mathrm{km}^{2}\right)\end{array}$ & $\begin{array}{l}\text { Total basin size } \\
\left(\mathrm{km}^{2}\right)\end{array}$ & $\begin{array}{l}\text { Floodplain width } \\
(\mathrm{km})\end{array}$ \\
\hline Spring Creek (Lower) & Unchannelized & 34 & 21 & 0 & 294 & 294 & 1.0 \\
\hline Spring Creek (Sain) & Unchannelized & 34 & 18 & 0 & 272 & 294 & 1.2 \\
\hline Bear Creek & Valley plug & 30 & 10 & 80 & 97 & 105 & 1.5 \\
\hline Jeffers Creek & Valley plug & 16 & 18 & 80 & 78 & 89 & 1.0 \\
\hline Hickory Creek & Valley plug & 21 & 18 & 60 & 42 & 47 & 1.0 \\
\hline
\end{tabular}


at two of the unchannelized sites (Spring GVL and Lower Spring) and two of the valley plug sites (Hickory Creek and Jeffers Creek). Sediment deposition rates were measured from 2003 to 2005 at additional sites, including the third unchannelized site (Spring-Sain), the third valley plug site (Bear Creek), and both shoal sites (Piney Creek and Porters Creek). At unchannelized sites, we measured deposition at plots spaced $\sim 100 \mathrm{~m}$ apart along transects perpendicular to the stream channel and spaced $\sim 200 \mathrm{~m}$ apart. Sediment sampling plots at unchannelized sites were spaced at greater distances than those at valley plug and shoal sites because of lower variability in deposition rates associated with unchannelized streams, based on previous studies and field observations (Hupp and Morris, 1990; Hupp and Bazemore, 1993; Kleiss, 1996). Similar sampling designs were used for shoal and valley plug sites, with plots spaced $50 \mathrm{~m}$ apart along transects perpendicular to the stream channel and spaced $\sim 50 \mathrm{~m}$ apart. At valley plug sites, transects were centered at the head of the valley plug and placed every $50 \mathrm{~m}$ in both directions (upstream and downstream) for a distance of $\sim 200 \mathrm{~m}$. At shoal sites, transects started at the confluence of the tributary with the Hatchie River and extended $\sim 300 \mathrm{~m}$ upstream. Floodplains on both sides of the tributaries were sampled at unchannelized and valley plug sites, but only on one side of the tributary at each shoal site because of a lack of landowner permission. At all sites, the length of each transect and number of sampling plots depended on floodplain morphology and landowner permission. A total of 183 plots at valley plug sites, 62 plots at shoal sites, and 30 plots at unchannelized sites were sampled.

Deposition rates at all sites were estimated by two different methods, depending on the situation. First, sedimentation pads made of white feldspar clay were installed at all sampling plots (Bauman et al., 1984; Cahoon and Turner, 1989). Pads were 2$3 \mathrm{~cm}$ thick and $\sim 1 \mathrm{~m}$ in diameter and were marked with a vertical $1.5 \mathrm{~m}$ PVC pipe on the north side of the pad. In addition, we marked a nearby tree and measured the direction and distance from the tree to the pad center to document pad location (Hupp and Bazemore, 1993; Hupp, 2000). We monitored sedimentation rates by measuring the amount of sediment that accumulated on the highly visible white marker pad; measurements were taken once a year, in triplicate, and averaged together. Refer to Cahoon and Turner (1989) for details on this method.

Initially, sediment pads were used for all sites. However, apparently this method was inappropriate for high deposition sites because pads could not be relocated. Thus, at locations experiencing high deposition rates, we used PVC pipe to determine deposition rates. A $1.5 \mathrm{~m}$ section of PVC pipe was driven into the ground, and we recorded the distance from the top of the pipe to the ground surface. This distance was remeasured once a year (when sediment pads were checked) to determine the amount of deposition. These two methods were used to measure annual sediment deposition rates.

We used the texture-by-feel analysis to evaluate sediment deposition texture in the field (Thein, 1979). Sediment texture was estimated at 183 valley plug plots, 62 shoal plots, and 30 unchannelized plots. Textures were classified as silt, sand/silt, or sand. These measurements were laboratory checked by obtaining sediment samples next to sediment pads or poles at 104 valley plug plots, 41 shoal plots, and all 30 unchannelized plots. Sediment samples were submitted to A\&L Laboratories (Memphis, TN) for textural analysis of percent sand, silt, and clay.

\subsection{Analysis}

To validate grouping sites of the same type together, we conducted ANOVA or $t$-tests, depending on the number of sites, to determine differences in deposition rates among sites of the same type. These analyses justified the grouping of study plots by site type for the site-level analysis. Site-level analyses of sediment deposition included ANOVA tests to determine differences in sedimentation rates among site types (valley plug, shoal, and unchannelized). Differences in sediment texture by site type were tested using randomization tests (Sokal and Rohlf, 1995).

Kruskal-Wallis tests were used in cases where ANOVA assumptions were invalid, and Tukey-Kramer multiple comparison tests were used to distinguish differences among groups $(\alpha=0.05)$ (Sokal and Rohlf, 1995). Statistical analyses were conducted with SAS Version 9.1 (SAS Institute Inc., 2004) and NCSS (Hintze, 2001).

\subsection{Geostatistical analysis}

To determine spatial patterns of sedimentation rates, we performed a geostatistical analysis on deposition rates at all three valley plug sites, both shoal sites, and one unchannelized site (Spring Creek-GVL) using the Geostatistical Analyst in ArcGIS Version 9.0 (ESRI, 2004). Small sample size and low variability in deposition rates at the other unchannelized sites excluded these sites from this analysis. Data sets were examined for normal distributions and local stationarity (Isaaks and Srivastava, 1989; Aurenhammer, 1991). Non-normal data were corrected using a normal score transformation that ranks the data and matches the ranks to ranked values of a normal distribution (Hohn, 1999).

First, omnidirectional variograms (no directionality) were calculated to determine the average degree of similarity of deposition rates between sample plots (Le Corre et al., 1998). Variograms were calculated using distance classes (Barbujani, 1988), such that the number of distance classes (lags) multiplied by the size class (lag size) was less than one-half the maximum distance between pairs of sample plots (Le Corre et al., 1998). Number of lags and lag size were adjusted for size of each study site to validate the distance class rule.

Variogram model fit was determined by cross-validation on the residuals of the predicted values (Isaaks and Srivastava, 1989). We also calculated an index of spatial dependence, based on the inverse of the relative nugget effect or the ratio of the partial sill to the total sill (Gross et al., 1995). Variograms were then adjusted for anisotropy to determine the maximum direction of spatial continuity (Isaaks and Srivastava, 1989). The directional axis for maximum spatial continuity was based on 
Table 2

Study sites with the number of plots used to estimate mean annual deposition rates ( \pm 1 standard error) and the percentage of plots at each site for each texture category of sediment deposited at the site

\begin{tabular}{|c|c|c|c|c|c|c|c|}
\hline Site & Site type & Number of plots & Number of times sampled & Mean annual deposition $(\mathrm{cm} / \mathrm{y})$ & Percent sand & Percent silt/sand & Percent silt \\
\hline Spring Creek (Lower) & Unchannelized & 10 & 3 & $0.67(0.20)$ & 0 & 10 & 90 \\
\hline Spring Creek (Sain) & Unchannelized & 9 & 2 & $0.09(0.05)$ & 0 & 0 & 100 \\
\hline Spring Creek (GVL) & Unchannelized & 11 & 3 & $0.38(0.10)$ & 0 & 0 & 100 \\
\hline Bear Creek & Valley plug & 64 & 3 & $4.15(0.38)$ & 34 & 44 & 22 \\
\hline Jeffers Creek & Valley plug & 54 & 3 & $3.44(0.54)$ & 30 & 24 & 46 \\
\hline Hickory Creek & Valley plug & 65 & 3 & $6.20(1.03)$ & 40 & 17 & 43 \\
\hline Piney Creek & Shoal & 31 & 2 & $2.27(1.15)$ & 16 & 23 & 61 \\
\hline Porters Creek & Shoal & 31 & 2 & $0.16(0.03)$ & 0 & 0 & 100 \\
\hline
\end{tabular}

a $0-360^{\circ}$ scale. Kriging was used in conjunction with the variogram to predict deposition rates at unsampled locations (Isaaks and Srivastava, 1989; Le Corre et al., 1998) and produce the predicted deposition maps of each floodplain.

\section{Results}

\subsection{Deposition rates}

Mean annual deposition rates varied little among sites of the same type (Table 2). No differences were found in the overbank deposition rates between the two shoal sites $(N=62, T=1.84$, $P=0.07)$ or among the three valley plug sites $(N=183, d f=2$, $\left.X^{2}=4.32, P=0.12\right)$. The three unchannelized sites did differ $(N=30, d f=2, F=4.40, P=0.02)$. The unchannelized Spring-Sain site had a lower deposition rate $(\overline{\mathrm{x}}=0.09 \pm 0.05 \mathrm{~cm} / \mathrm{y}, \overline{\mathrm{x}}=$ mean \pm 1 standard error) than the Lower Spring site $(\overline{\mathrm{x}}=0.67 \pm 0.20 \mathrm{~cm} / \mathrm{y})$. However, differences in deposition rates between the Spring-Sain and Lower Spring sites did not affect the overall ANOVA based on site type. The results of these analyses justified the grouping of sites by type for the remainder of the analysis.

Sedimentation rates were greater at valley plug sites $(\overline{\mathrm{x}}=4.67 \pm$ $0.43 \mathrm{~cm} / \mathrm{y})$ than shoal $(\overline{\mathrm{x}}=1.21 \pm 0.59 \mathrm{~cm} / \mathrm{y})$, and unchannelized sites $(\overline{\mathrm{x}}=0.39 \pm 0.09 \mathrm{~cm} / \mathrm{y})(N=275, d f=2, F=15.98, P<0.001)$. The greatest amount of sediment deposited at a plot in one year occurred at the Hickory Creek valley plug site in 2003, measuring $79.5 \mathrm{~cm}$. Of the 183 valley plug plots, 22 plots averaged over $10 \mathrm{~cm} / \mathrm{y}$ of deposition during the study period and 58 plots averaged over $5 \mathrm{~cm} / \mathrm{y}$. The deepest deposition measured at a shoal plot was $32 \mathrm{~cm}$ in 2004 at the Piney Creek shoal site. Both shoal sites only had two plots with deposition rates $>5 \mathrm{~cm} / \mathrm{y}$; both occurred at the Piney Creek shoal site. The largest deposition event we measured at an unchannelized plot was $1.65 \mathrm{~cm}$ on the floodplain at the Lower Spring Creek site.

The laboratory textural analysis confirmed the accuracy of our texture-by-feel analysis. The laboratory analysis showed that sediment classified in the field as sand, contained an average $80 \%$ sand. The silt/sand classification averaged $67 \%$ sand and $33 \%$ silt and clay. The silt classification averaged $52 \%$ silt and clay and $48 \%$ sand. Randomization tests determined differences in the proportion of plots of each site type that experienced deposition of each textural classification (Table 2). A greater proportion of plots at valley plug sites contained sand and silt/sand deposits than at unchannelized sites $(N=213$,
$T 2=6.033, P<0.001)$ and shoal sites $(N=245, T 2=5.986$, $P=0.001)$. Shoal sites also had a greater proportion of plots containing sand and silt/sand deposits than unchannelized sites $(N=92, T 2=2.128, P=0.041)$.

\subsection{Geostatistical analysis}

For all study sites examined with geostatistical methods, the best-fitting variogram models produced standardized mean residuals ranging from 0.015 to 0.060 and root-mean-squared standardized errors from 0.841 to 1.112 , indicating good model fit. All study sites had a major range near the maximum of distance classes examined, showing that deposition rates were correlated within each study site. All variograms showed an increase in value with increased distance and presence of a sill, demonstrating spatial dependence. Anisotropy was evident among variograms of each study site, but the direction of spatial dependence varied among sites. The index of spatial dependence varied among study sites, but was high for all sites except the Piney Creek shoal site (Table 3).

For the Spring Creek-GVL unchannelized site, an exponential model was the best fit to calculate the variogram of deposition rates (Table 3). The direction of spatial dependence was similar to the direction of stream flow (Fig. 4). The prediction map of Spring Creek-GVL (Fig. 4) showed that the greatest deposition rates, which did not exceed $1 \mathrm{~cm} / \mathrm{y}$, occurred along the main stream channel and a secondary stream channel.

The index of spatial dependence for the Porters Creek shoal site was high at $99.9 \%$, showing strong spatial correlation of

Table 3

Variogram models, index of spatial dependence of sediment deposition, and orientation of the direction of maximum spatial continuity to the direction of streamflow (parallel $=+/-20^{\circ}$ of streamflow, acute $=$ between 20 and $70^{\circ}$ of streamflow, and perpendicular $=+/-20^{\circ}$ of orthogonal orientation to streamflow)

\begin{tabular}{lllll}
\hline Site & Site type & $\begin{array}{l}\text { Variogram } \\
\text { model }\end{array}$ & $\begin{array}{l}\text { Spatial } \\
\text { dependence }\end{array}$ & $\begin{array}{l}\text { Orientation relative } \\
\text { to streamflow }\end{array}$ \\
\hline $\begin{array}{llll}\text { Spring-GVL } \\
\text { Porters }\end{array}$ & $\begin{array}{l}\text { Unchannelized } \\
\text { Shoal }\end{array}$ & $\begin{array}{l}\text { Exponential } \\
\text { Rational } \\
\text { quadratic }\end{array}$ & $\begin{array}{l}81.4 \% \\
99.9 \%\end{array}$ & $\begin{array}{l}\text { Parallel } \\
\text { Parallel }\end{array}$ \\
Piney & Shoal & Gaussian & $24.9 \%$ & Acute \\
Hickory & Valley plug & Exponential & $82.9 \%$ & Acute \\
Jeffers & Valley plug & Gaussian & $64.4 \%$ & Perpendicular \\
Bear & Valley plug & Exponential & $64.6 \%$ & Perpendicular \\
\hline
\end{tabular}




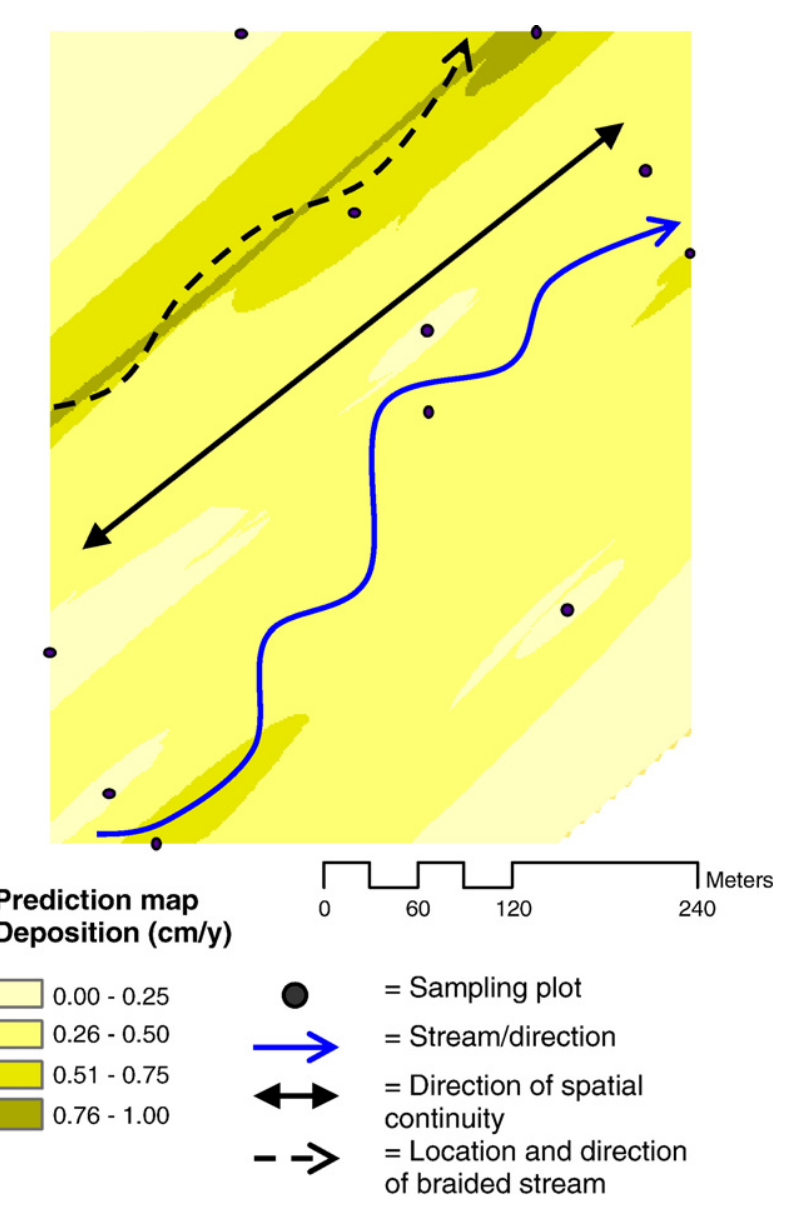

Fig. 4. Prediction map of sediment deposition occurring at the Spring CreekGVL unchannelized site from 2002 to 2005 .

deposition rates (Table 3). Similar to the unchannelized site, the direction of spatial dependence corresponded with the direction of stream flow (Fig. 5). The kriged map (Fig. 5) predicted that no areas experienced deposition rates exceeding $0.50 \mathrm{~cm} / \mathrm{y}$.

The Piney Creek shoal site had the lowest index of spatial dependence at $24.9 \%$ because of the large relative nugget effect (Table 3). The prediction map (Fig. 6) showed that the direction of spatial dependence was at a $65^{\circ}$ angle to the stream flow of Piney Creek. The prediction map included approximately $144,290 \mathrm{~m}^{2}$ of the Piney Creek floodplain. Approximately $31 \%$ of this area was receiving $>2.00 \mathrm{~cm} / \mathrm{y}$ of sediment deposition.

Similar to the Porters Creek shoal and the unchannelized Spring Creek-GVL sites, the variogram calculated for the Hickory Creek valley plug site had a high index of spatial dependence at $82.9 \%$ (Table 3). The most interesting result for this geostatistical analysis is the direction of spatial dependence, which is at approximately a $50^{\circ}$ angle to the stream flow (Fig. 7). The prediction map also illustrates that approximately $81 \%$ of the $238,840 \mathrm{~m}^{2}$ area included in the prediction map was receiving $>1.50 \mathrm{~cm} / \mathrm{y}$ of sediment deposition, and $50 \%$ of the area was receiving $>5.00 \mathrm{~cm} / \mathrm{y}$.

At the Bear Creek valley plug site, the prediction map showed that approximately $70 \%$ of the $170,740 \mathrm{~m}^{2}$ area included in the map (Fig. 8) received deposition in excess of
$3.00 \mathrm{~cm} / \mathrm{y}$. Moreover, the direction of spatial dependence at the Bear Creek site was perpendicular to stream flow.

The Jeffers Creek valley plug site exhibited a similar spatial pattern in deposition rates as the Hickory Creek and Bear Creek valley plug sites, as the direction of spatial dependence was perpendicular to stream flow (Fig. 9). Approximately $50 \%$ of the $244,560 \mathrm{~m}^{2}$ area included in the prediction map of Jeffers Creek was subject to deposition $>3.00 \mathrm{~cm} / \mathrm{y}$. Interestingly, at the Jeffers Creek valley plug site, the area downstream of the valley plug experienced the highest rates of deposition (Fig. 9), unlike the other valley plug sites where the highest rates of deposition occurred upstream of the valley plug.

\section{Discussion}

\subsection{Deposition rates}

Deposition rates and the types of deposited sediment have been strongly affected by the formation of valley plugs and shoals in the channelized tributaries of the Hatchie River. The formation of valley plugs seems to have a more dramatic impact than shoals on deposition rates; however, our results do suggest that shoals may also affect deposition rates in at least some distinct areas. The results also suggest that there can be considerable variability in sedimentation responses to the formation of valley plugs and shoals.

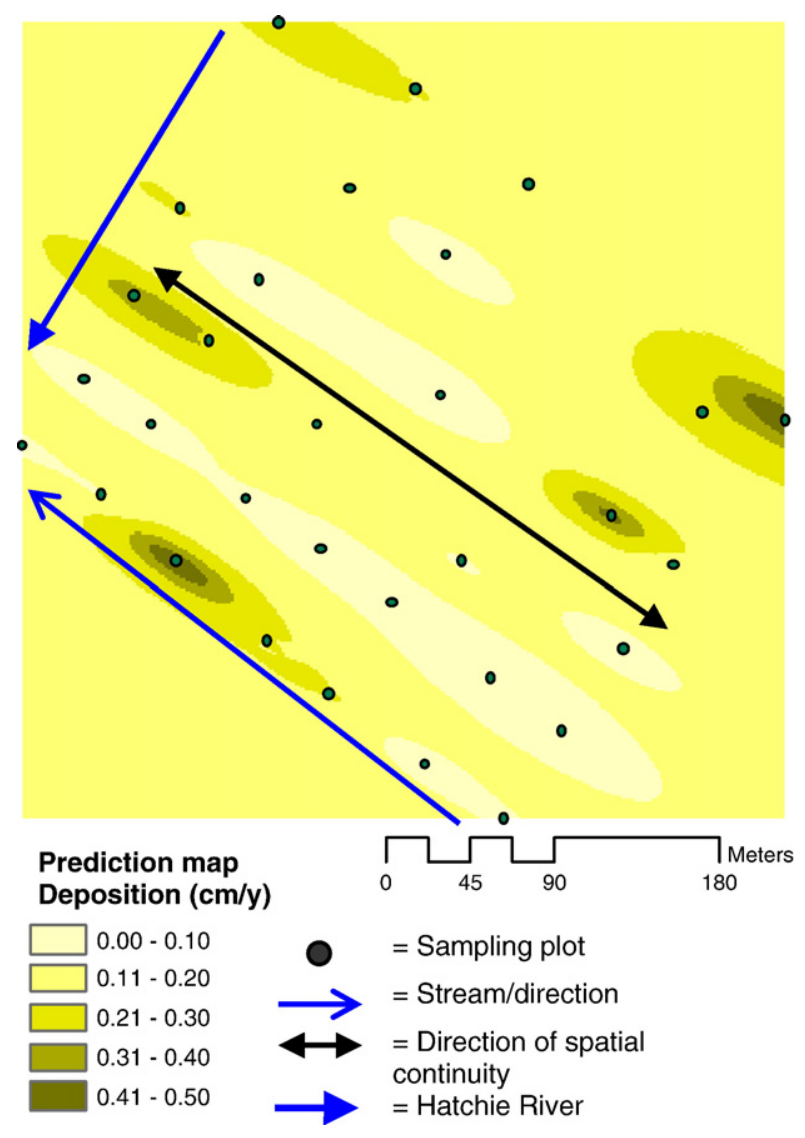

Fig. 5. Prediction map of sediment deposition occurring at the Porters Creek shoal site from 2003 to 2005 . 


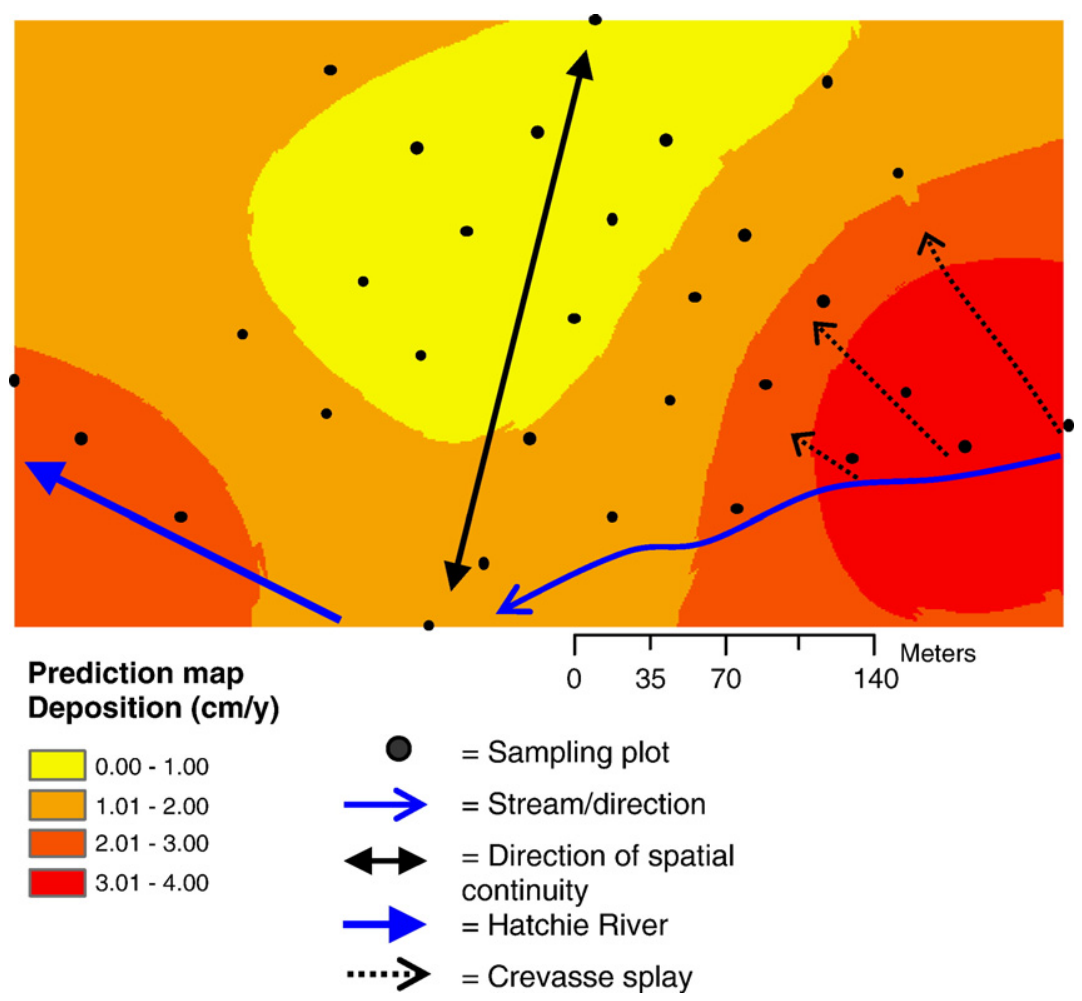

Fig. 6. Prediction map of sediment deposition occurring at the Piney Creek shoal site from 2003 to 2005.

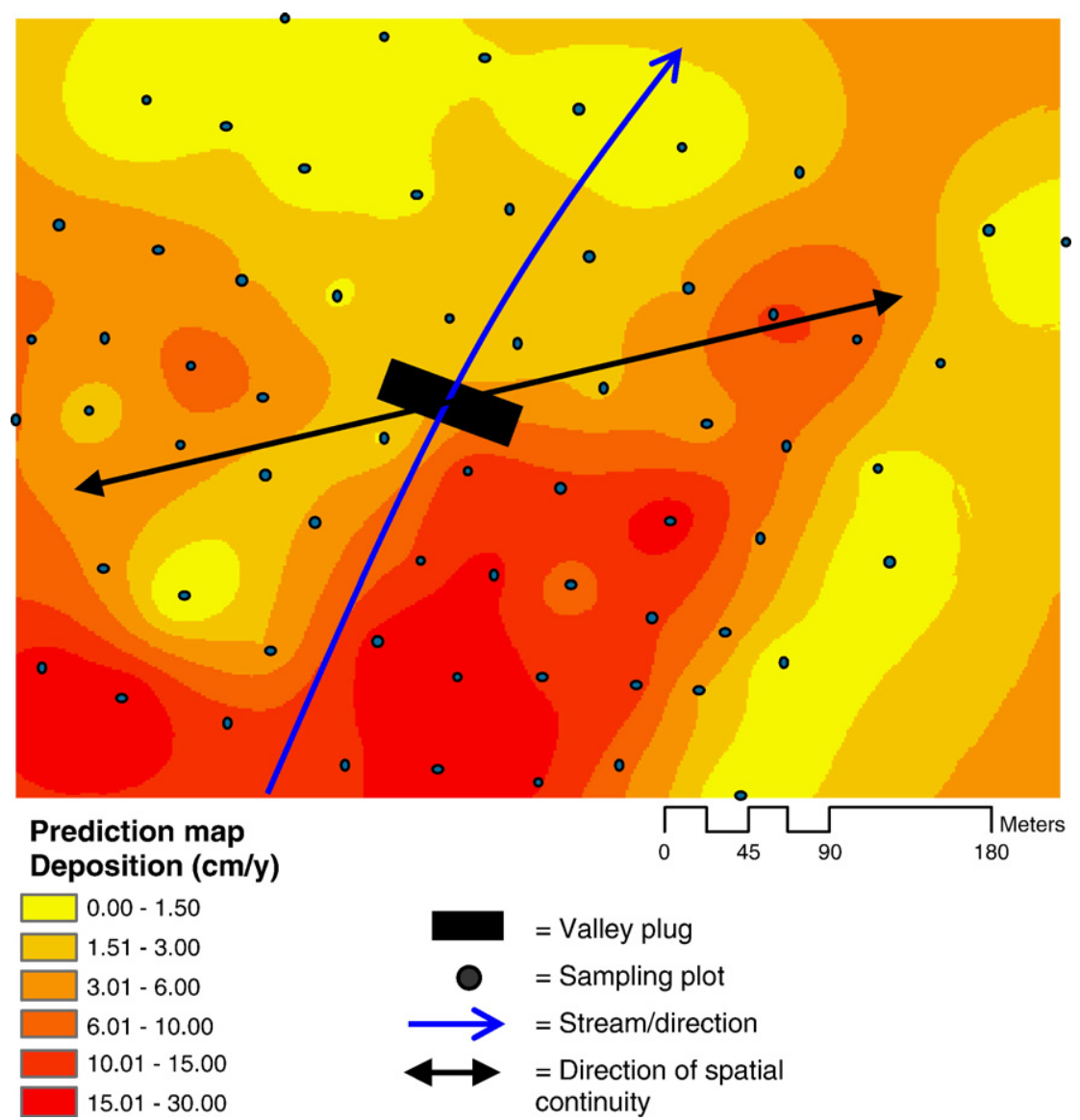

Fig. 7. Prediction map of sediment deposition occurring at the Hickory Creek valley plug site from 2002 to 2005. 


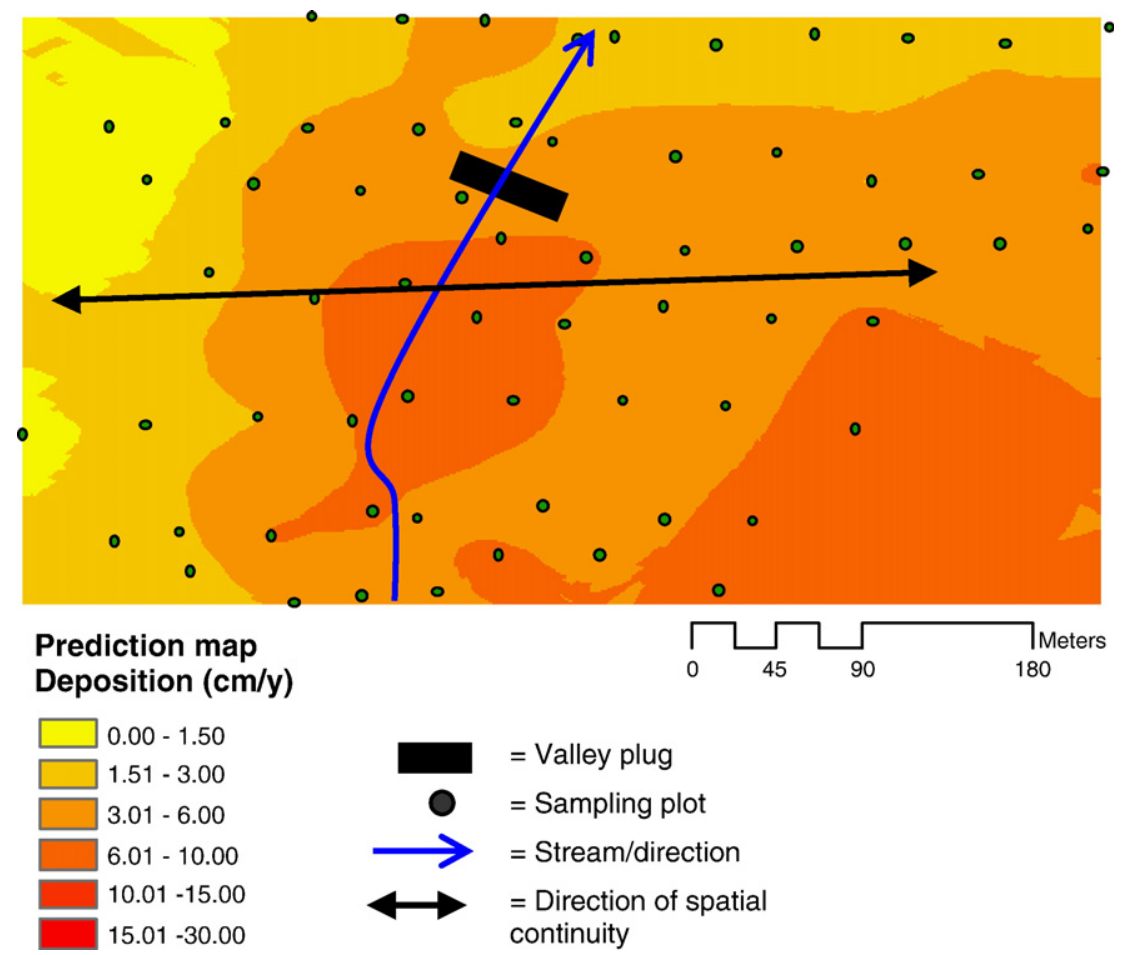

Fig. 8. Prediction map of sediment deposition occurring at the Bear Creek valley plug site from 2003 to 2005.

Mean deposition rates at unchannelized and shoal sites were within the range of deposition rates reported in previous studies (Table 4). The type of sediment deposited at unchannelized sites was typical of most overbank floodplain deposits, consisting of mostly silt and clay particles. Although the shoal and unchannelized sites did not differ in mean deposition rate, our
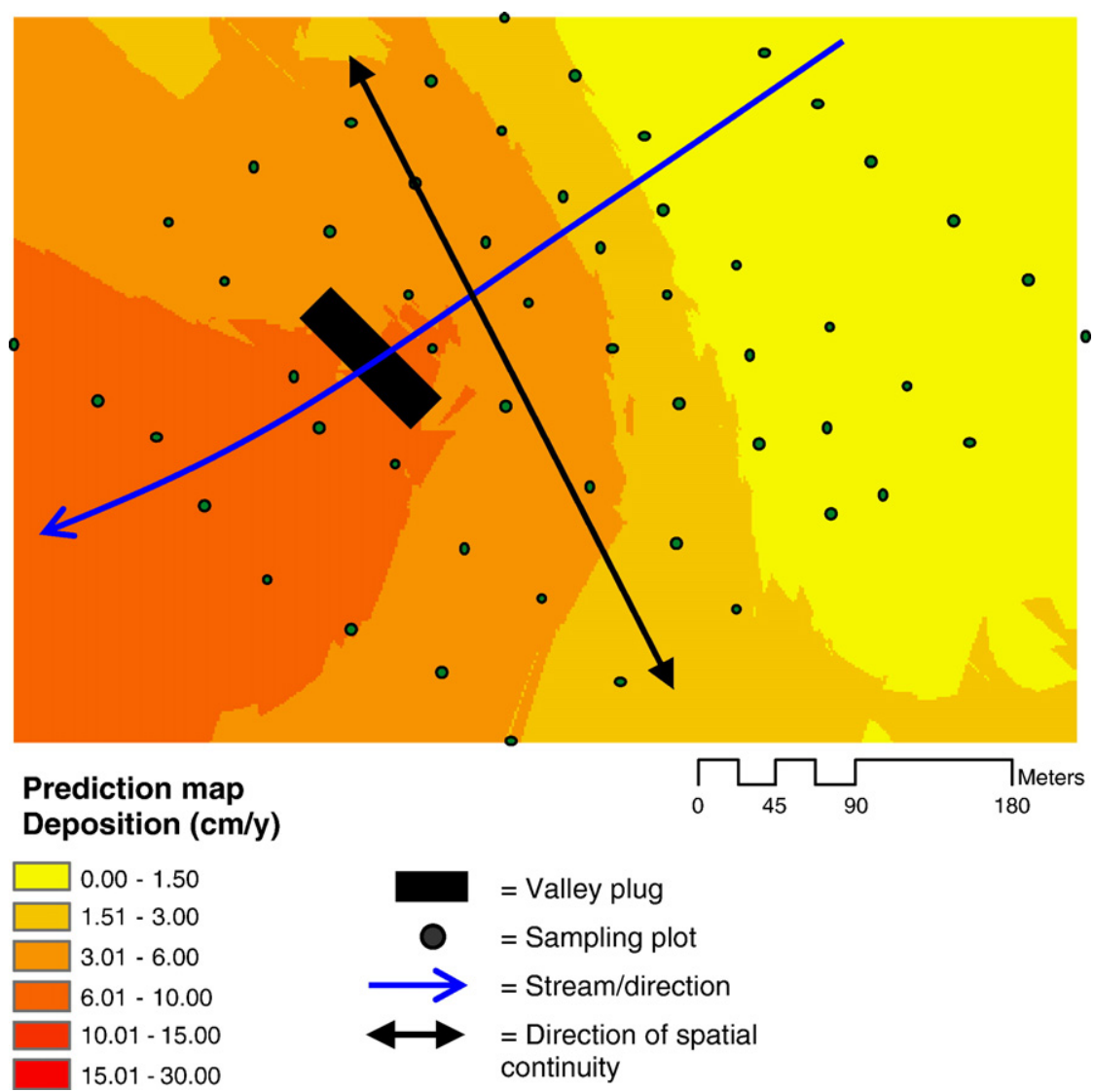

Fig. 9. Prediction map of sediment deposition occurring at the Jeffers Creek valley plug site from 2002 to 2005. 
results suggest that channelization and presence of a shoal may influence sedimentation rates. For example, the Piney Creek shoal site experienced greater deposition of coarse sand (two deposition measurements greater than $5 \mathrm{~cm} / \mathrm{y}$ ) in certain distinct areas. These areas corresponded to low areas in the spoil bank or natural levee along the channel where crevasse splays formed during overbank flood events. Shoals may encourage the formation of crevasse splays by increasing within-channel deposition upstream of the shoal as a result of reduced water flows, slowed by the presence of the shoal at the confluence. Channel deposits fill in the channel with sediment; and reduce the distance between the channel bed and low points in the spoil bank or natural levee, increasing the frequency of high velocity overbank flows that can transport and deposit coarse sediment on the floodplain.

Deposition rates measured at valley plug sites were significantly greater than deposition rates at shoal and unchannelized sites. The greater deposition rate at valley plug sites compared to shoal sites also suggests that the greater deposition rates may be the result of the valley plug, not just a result of channelization of the stream. In addition, sediment deposited at over one-third of the valley plug plots consisted of coarse sand. In contrast, deposition at shoal and unchannelized sites was composed mostly of silt with only 5 out of 92 plots having sand deposits. Sand is typically transported as bedload and would only be deposited on floodplains during overbank flooding with high velocity flows. This condition is probably much more common at valley plug sites, where the channelized system can sustain high velocity flows and the valley plug completely blocks the channel, forcing all stream flow into the floodplain (Happ et al., 1940). At unchannelized and shoal sites, the channel is not blocked and overbank flooding only occurs during high flood events that inundate the floodplain for long time periods, promoting the deposition of fine sediments like silt and clay (Happ et al., 1940; Hodges, 1997). Overbank flows at unchannelized and shoal sites are probably not powerful enough to transport large amounts of coarse sediment onto the floodplain, except in areas associated with crevasse splays.

Although channelized streams typically carry heavier sediment loads than unchannelized streams (USDA, 1970;

Table 4

The range in mean deposition rate $(\mathrm{cm} / \mathrm{y})$ and overall mean rate for previous studies conducted in the southeastern U.S. and the rates from our three site types

\begin{tabular}{|c|c|c|}
\hline Study site & $\begin{array}{l}\text { Range of deposition rate } \\
(\mathrm{cm} / \mathrm{y})\end{array}$ & Authors \\
\hline Black Swamp, AR & $0.01-0.60($ mean $=0.28)$ & Hupp and Morris, 1990 \\
\hline Reelfoot Lake, TN & $0.00-2.60$ & $\begin{array}{l}\text { McIntyre and Naney, } \\
1991\end{array}$ \\
\hline Western TN, after 1960 & $0.00-0.99($ mean $=0.26)$ & $\begin{array}{l}\text { Hupp and Bazemore, } \\
1993\end{array}$ \\
\hline Cache River, AR & $0.02-2.64($ mean $=0.82)$ & Kleiss, 1996 \\
\hline $\begin{array}{l}\text { Missouri River, } \\
\text { 1995-98 }\end{array}$ & $0.03-0.64($ mean $=1.00)$ & Heimann and Roell, 2000 \\
\hline Unchannelized sites & $0.00-1.65($ mean $=0.39)$ & Pierce and King \\
\hline Shoal sites & $0.01-17.80($ mean $=1.21)$ & Pierce and King \\
\hline Valley plug sites & $0.00-41.55($ mean $=4.67)$ & Pierce and King \\
\hline
\end{tabular}

Simon, 1994; Hopkinson and Vallino, 1995), lower rates of deposition have been associated with channelized streams because of the reduced lateral connectivity between the stream and the floodplain. Hupp and Bazemore (1993) reported higher deposition rates on floodplains of the unchannelized Hatchie River main stem compared to the floodplain of the channelized Big Sandy River in western Tennessee. They attributed their results to the reduced lateral connectivity of the channelized system to the floodplain. Substantial deposits, such as at our valley plug sites, are often episodic and correspond to infrequent large flood events that exceed geomorphic thresholds, resulting in the mass movement of sediment (Schumm et al., 1984; Asselman and Middelkoop, 1998; Middelkoop and Asselman, 1998; Walling et al., 1998; Kasai et al., 2004). Anthropogenic disturbances, including channelization and land-use changes, can influence these thresholds by either lowering them or by facilitating conditions that allow processes to exceed them more readily (Dietrich et al., 1992; Brooks and Brierley, 2004). Several studies have demonstrated similar geomorphic adjustments of the semi-alluvial rivers in southeastern Australia following European settlement (Brierley and Murn, 1997; Fryirs and Brierley, 1998; Brooks and Brierley, 2000, 2004).

Basin size can also have a significant effect on floodplain sedimentation rates (Knighton, 1998; Hupp, 2000; Steiger et al., 2003). Typically, larger basins have the potential for greater deposition rates. At our sites, basin size did vary greatly (Table 1), and therefore may have influenced our results. However, Spring Creek was the largest basin and had the lowest deposition rates. This indicates that channelization and the formation of valley plugs and shoal may have more influence on sedimentation rates than some basin-level factors. Valley plugs and shoals are also not restricted to small basins, but are also common in large basins within the region, such as the Forked Deer River basin in western Tennessee (Oswalt and King, 2005).

Valley plugs and the location of these sites within the basin are largely responsible for the differences between the results of our study and previous studies of floodplain deposition rates that were not influenced by valley plugs (Hupp, 1992; Hupp and Bazemore, 1993; Kleiss, 1996; Ross et al., 2004). The formation of valley plugs has reconnected the channelized stream to the floodplain and caused greater deposition rates in the floodplain. Numerous distributaries, created by high velocity flows as water was forced onto the floodplain at the valley plug, were also observed at valley plug sites. These distributaries, which ranged in width from approximately 0.5 to $2.5 \mathrm{~m}$, facilitate the transport of coarse sand into the floodplain during overbank flooding events. Future deposition rates at valley plug sites may be extremely variable, as high deposition can dramatically change the floodplain morphology over short periods and alter depositional patterns. Valley plugs also have the potential to rapidly expand upstream and affect new floodplain areas. For example, during our study, the valley plug at the Hickory Creek site expanded $80 \mathrm{~m}$ upstream in less than one year. Thus, the duration that a 
floodplain may experience high rates of deposition as a result of valley plug formation and the rate of plug expansion may be extremely variable among sites, depending mainly on upstream sources of sediment and the ability of the stream to transport the sediment downstream.

Models have been developed to understand the geomorphic readjustments and recovery processes of channelized streams (Schumm et al., 1984; Simon and Hupp, 1987). Both models predict fluvial-geomorphic changes after channelization; however, neither model addresses how the formation of valley plugs, which are common in western Tennessee and northern Mississippi (Happ et al., 1940; Diehl, 2000), affect fluvialgeomorphic processes or how continued dredging activities, mainly by private landowners, have affected these processes. Simon and Hupp (1987) and Hupp (1992) developed a model of vegetation recolonization following channelization. The patterns of vegetation recolonization described in their model corresponded with geomorphic readjustments. The final two stages of Simon and Hupp's model involves aggradation and widening of the channel (Stage V and VI), leading to the recovery of both the vegetation and a meandering channel. Schumm et al. (1984) described similar stages and processes of channel recovery following channelization; however, their conceptual model of recovery includes all stages of recovery occurring simultaneously along the gradient of the channelized stream from the headwaters to the confluence with other streams. The aggradation stage (Stage V) and recovery stage (Stage VI) of Simon and Hupp (1987) corresponds to lowgradient areas of the depositional zone in the model described by Schumm et al. (1984), where the channel widens and becomes shallower because of accumulating sediment until the channel and banks become stabilized. Valley plugs typically form in these low-gradient areas because of reduced flow velocities. Valley plugs may be a part of the aggradation process of channel recovery following channelization, but the accumulation of sediment in channelized systems within the region has been exacerbated by the geology of the region, past land-use practices, and unstable gullies and stream banks that contribute sediment to the systems (Happ et al., 1940; Hupp, 1992; Saucier, 1994), resulting in extremely high deposition rates of coarse material. Valley plugs and the associated high deposition rates may therefore be controlled by both basin-level factors (geology and land use) and site-level factors (stream gradient, debris jams, and channel recovery processes).

\subsection{Geostatistical analysis}

The geospatial analysis was effective in revealing the differences of valley plugs and shoals on the spatial dynamics of overbank sedimentation. Channelization and the subsequent formation of valley plugs can have a profound effect on the spatial dynamics of deposition rates in addition to typical factors such as sediment load and frequency and magnitude of floods. Shoals also influenced the spatial dynamics of overbank sedimentation; however, the responses were more variable.

The index of spatial dependence was relatively high at all study sites, except for the Piney Creek shoal site, indicating a high degree of spatial correlation of deposition rates within floodplains with respect to both distance and direction. The low index of spatial dependence at the Piney Creek shoal site indicates a large amount of spatial variability in deposition rates within the floodplain. As discussed earlier in the deposition section, most of the deposition occurring at the Piney Creek shoal site was within the range of previous studies. However, as estimated through kriging, nearly $30 \%$ of the floodplain experienced sedimentation rates $>2.0 \mathrm{~cm} / \mathrm{y}$ as a result of their association with crevasse splays. The crevasse splays break up the spatial continuity of the otherwise average deposition rates found in floodplain forests. The impact of crevasse splays is also evident by the skewed direction of spatial dependence, which is at a $65^{\circ}$ angle to the direction of stream flow (Fig. 6).

One of the most interesting results from the geostatistical analyses is the direction of spatial continuity, which varied by site type ranging from parallel to stream-flow to perpendicular to stream-flow. Based on our current understanding of sedimentation, one would expect the direction of spatial continuity to be in the direction of stream flow because the stream is the conduit for sediment transport causing most deposition to occur along the channel (Knighton, 1998). The spatial patterns found at the Spring Creek unchannelized site and Porters Creek shoal site were similar to each other and supported the spatial patterns that were predicted based on our current understanding of sedimentation in floodplains. They had a high degree of spatial dependence $(81.4 \%$ and $99.9 \%$, respectively) in the direction of stream flow. At these sites, some isolated areas did receive greater deposition rates $(\geq 2 \mathrm{~cm} / \mathrm{y})$, which correspond to depressions within the floodplain that experience longer periods of inundation than the rest of the floodplain. Deposition rates over the entire prediction map, however, are within the range of previous studies. The similarities in spatial patterns of deposition at the Spring Creek and Porters Creek sites suggest that under some circumstances deposition dynamics may not be influenced by the formation of a shoal; however, this may change in the future if the shoal continues to develop.

At the three valley plug sites, valley plug formation has influenced the sedimentation dynamics at the site. The valley plugs forced sediment several hundred meters into the floodplain on both sides of the channel, resulting in a direction of spatial dependence that is perpendicular instead of parallel to stream flow. The contour maps produced through kriging also demonstrate that the excessive sedimentation resulting from valley plug formation can impact a large portion of the floodplain, not just isolated areas near the plug. In the case of the Hickory Creek and Bear Creek valley plug sites, the deposition maps (Figs. 7 and 8) showed that the greatest deposition rates occurred in floodplain areas upstream of the valley plugs. In contrast, the Jeffers Creek valley plug site had greater rates of deposition in floodplain areas downstream of the valley plug. Dredging and within-stream channel alterations by private landowners, which would allow sediments to move farther downstream, may be the reason for this discrepancy. Such activity that has occurred at the Jeffers Creek valley plug site 
would reset the development of the valley plug and allow for the accumulation of sediment downstream of the dredged plug.

\section{Conclusion}

Channelization of streams in the Hatchie River watershed has significantly altered fluvial-geomorphic processes on a basinwide scale (Boulton, 2005; Pierce, 2005). Valley plugs and shoals within these channelized systems are symptoms of fluvial-geomorphic processes that have been altered as a result of channelization and the geological and past land-use practices of the region (Happ et al., 1940; Diehl, 2000; Pierce, 2005). The formation of valley plugs in channelized tributaries has resulted in greater overbank deposition rates with deposits consisting of more coarse material than the deposits in floodplains adjacent to unchannelized streams both within the Hatchie River watershed and throughout the southeastern United States (Hupp and Morris, 1990; Hupp and Bazemore, 1993; Kleiss 1996; Heimann and Roell, 2000). The spatial patterns of overbank sedimentation also differ from the patterns expected and observed in unchannelized systems. Shoals may also influence overbank sedimentation in certain situations where crevasse splays develop, but the responses seem more variable than floodplains affected by valley plugs.

The formation of valley plugs and shoals may be a part of the recovery process from channelization. However, the timescale needed for the system to repair itself and the associated costs from excessive sedimentation on integrity of the floodplain system and on the functions provided by the floodplain (including flood storage, water quality enhancement, wildlife habitat, and timber value) (Happ et al., 1940; Diehl, 2000; Oswalt and King, 2005; Pierce, 2005) may be unacceptable from a conservation perspective. Restoration efforts on tributaries in this study and in similar watersheds need to focus on stabilizing sediment supply into these systems, reducing flow velocities that transport sediment to the sites and onto the floodplains, and stabilizing bed-level adjustments over the entire drainage network. Individual dredging of within channel sediment deposits and other site-specific disturbances may hamper restoration efforts by setting back recovery processes; thus, cooperation on the watershed scale is needed for restoration efforts to be successful. The geomorphic instability of the region also requires that restoration efforts take a catchmentscale approach and recognize the importance of enhancing natural recovery mechanisms to restore floodplain functions and rehabilitate the ecosystem (Hillman and Brierley, 2005; Palmer et al., 2005).

\section{Acknowledgments}

Funding for this project was provided by the U.S.D.A. CSREES Initiative for Future Agricultural and Food Systems, the U.S. Fish and Wildlife Service, and The Nature Conservancy - Hatchie River Project. We would like to thank F. van Manen and L. Thompson for their assistance with the geospatial analysis and A. Wyss, G. Gallien, C. Wirwa, and D. Orr for their logistic support. We thank J. Nolte, E. Sawyers, C. Yoest, N.
Wirwa, B.J. Wilson, W. Cochran, J. Fox, and J. Roberson for their assistance in the field. We thank J. Weltzin, D. Buehler, C. Harden, J. Franklin, R. Albright, and S. Faulkner for providing constructive comments on this manuscript.

\section{References}

Asselman, N.E.M., Middelkoop, H., 1998. Temporal variability of contemporary floodplain sedimentation in the Rhine-Meuse Delta, The Netherlands. Earth Surface Processes and Landforms 23, 595-609.

Aurenhammer, F., 1991. Voronoi diagrams - a survey of a fundamental geometric data structure. ACM Computing Surveys 23, 345-405.

Barbujani, G., 1988. Detecting and comparing the direction of gene-frequency gradients. Journal of Genetics 67, 129-140.

Barstow, C.J., 1971. Impact of channelization on wetland habitat in the ObionForked Deer basin, Tennessee. In: Trefethen, J.B. (Ed.), Transactions of the Thirty-Sixth North American Wildlife and Natural Resources Conference. Wildlife Management Institute, Washington, DC, pp. 362-376.

Bauman, R.H., Dat, J.W., Miller, C.A., 1984. Mississippi deltaic wetland survival: sedimentation versus coastal submergence. Science 224, 1093-1095.

Bettis III, E.A., Zak, D.R., Denton, S.R., Spurr, S.H., 2003. Last glacial loess in the conterminous USA. Quarternary Science Reviews 22, 1907-1946.

Boulton, M., 2005. Spatio-temporal patterns of geomorphic adjustment in channelized tributary streams of the lower Hatchie River basin, West Tennessee. Ph.D. dissertation. University of Tennessee, Knoxville, TN.

Bravard, J.P., Amoros, C., Pautou, G., Bornette, G., Bournaud, M., Des Chatelliers, M.C., Gibert, J., Peiry, J.L., Perrin, J.F., Tachet, H., 1997. River incision in south-east France: morphological phenomena and ecological effects. Regulated Rivers: Research \& Management 13, 75-90.

Brierley, G.J., Murn, C.P., 1997. European impacts on downstream sediment transfer and bank erosion in Cobargo catchment, New South Wales, Australia. Catena 31, 119-136.

Brooks, A.P., Brierley, G.J., 2000. The role of European disturbance in the metamorphosis of Lower Bega River. In: Brizga, S.O., Finlayson, B.L. (Eds.), River Management: The Australasian Experience. Wiley, Chichester, UK, pp. 221-246.

Brooks, A.P., Brierley, G.J., 2004. Framing realistic river rehabilitation targets in light of altered sediment supply and transport relationships: lessons from East Gippsland, Australia. Geomorphology 58, 107-123.

Cahoon, D.R., Turner, R.E., 1989. Accretion and canal impacts in a rapidly subsiding wetland; II. Feldspar marker horizon technique. Estuaries 12, 260-268.

Diehl, T., 2000. Shoals and Valley Plugs in the Hatchie River Watershed. Report 00-4279. U.S. Geological Survey, Nashville, TN.

Dietrich, W.E., Wilson, C.J., Montgomery, D.R., McKean, J., Bauer, R., 1992. Erosion thresholds and land surface morphology. Geology 20, 675-679.

ESRI, 2004. ArcGIS Version 9.0. Redlands, California.

Fryirs, K., Brierley, G.J., 1998. The character and age structure of valley fills in upper Wolumla Creek, South Coast, New South Wales, Australia. Earth Surface Processes and Landforms 23, 271-287.

Gross, K.L., Pregitzer, K.S., Burton, A.J., 1995. Spatial variation in nitrogen availability in three successional plant communities. Journal of Ecology 83, 357-367.

Happ, S.C., 1975. Genetic classification of valley sediment deposits. In: Vanoni, V.A. (Ed.), Sedimentation Engineering. American Society of Civil Engineers, New York, NY, pp. 286-292.

Happ, S., Rittenhouse, G., Dobson, G., 1940. Some principles of accelerated stream and valley sedimentation. Technical Bulletin, vol. 695. U.S. Department of Agriculture, Washington, DC.

Heimann, D.C., Roell, M.J., 2000. Sediment loads and accumulation in a small riparian wetland system in Northern Missouri. Wetlands 20, 219-231.

Hillman, M., Brierley, G., 2005. A critical review of catchment-scale stream rehabilitation programmes. Progress in Physical Geography 29, 50-70.

Hintze, J., 2001. NCSS and PASS. Number Cruncher Statistical Systems. Kaysville, Utah.

Hodges, J.D., 1997. Development and ecology of bottomland hardwood sites. Forest Ecology and Management 90, 117-125. 
Hohn, M.E., 1999. Petroleum and Geostatistics. Kluwer Academic Publishers, Dordrecht, Germany.

Hopkinson, C.S., Vallino, J.J., 1995. The relationships among mans activities in watersheds and estuaries. Estuaries 18, 598-621.

Hupp, C., 1992. Riparian vegetation recovery patterns following stream channelization: a geomorphic perspective. Ecology 73, 1209-1226.

Hupp, C., 2000. Hydrology, geomorphology, and vegetation of Coastal Plain Rivers in the southeastern United States. Hydrological Processes 14, 2991-3010.

Hupp, C., Bazemore, D., 1993. Temporal and spatial patterns of wetland sedimentation, West Tennessee. Journal of Hydrology 141, 179-196.

Hupp, C., Morris, E., 1990. A dendrogeomorphic approach to measurement of sedimentation in a forest wetland, Black Swamp, Arkansas. Wetlands 10, $107-124$.

Isaaks, E.H., Srivastava, R.M., 1989. An Introduction to Applied Geostatistics. Oxford University Press, New York.

Kasai, M., Marutani, T., Brierley, G., 2004. Channel bed adjustments following major aggradation in a steep headwater setting: findings from Oyabu Creek, Kyushu, Japan. Geomorphology 62, 199-215.

Kleiss, B.A., 1996. Sediment retention in a bottomland hardwood wetland in Eastern Arkansas. Wetlands 16, 321-333.

Knighton, D., 1998. Fluvial Forms and Processes. Arnold, London, p. 383.

Le Corre, V., Roussel, G., Zanetto, A., Kremer, A., 1998. Geographical structure of gene diversity in Quercus petraea (Matt.) Liebl. III. Patterns of variation identified by geostatistical analyses. Heredity 80, 464-473.

McIntyre, S.C., Naney, J.W., 1991. Sediment deposition in a forested inland wetland with a steep-farmed watershed. Journal of Soil and Water Conservation 46, 64-66.

Middelkoop, H., Asselman, N.E.M., 1998. Spatial variability of floodplain sedimentation at the even scale in the Rhine-Meuse Delta, The Netherlands. Earth Surface Processes and Landforms 23, 561-573.

Middelkoop, H., Van Der Perk, M., 1998. Modelling spatial patterns of overbank sedimentation on embanked floodplains. Physical Geography 80, 95-109.

Nicholas, A.P., Walling, D.E., 1998. Numerical modelling of floodplain hydraulics and suspended sediment transport and deposition. Hydrological Processes 12, 1339-1355.

Oswalt, S.N., 2003. Evaluation and description of a floodplain system: the Middle Fork Forked Deer River, West Tennessee. M.S. Thesis. University of Tennessee, Knoxville, TN.

Oswalt, S.N., King, S.L., 2005. Channelization and floodplain forests: impacts of accelerated sedimentation and valley plug formation on floodplain forests of the Middle Fork Forked Deer River, Tennessee, USA. Forest Ecology and Management 215, 69-83.

Palmer, M.A., Bernhardt, E.S., Allan, J.D., Lake, P.S., Alexander, G., Brooks, S., Carr, J., Clayton, S., Dahm, C.N., Follstad Shah, J., Galat, D.L., Loss, S.G., Goodwin, P., Hart, D.D., Hassett, B., Jenkinson, R., Kondolf, G.M., Lave, R., Meyer, J.L., O’Donnell, T.K., Pagano, L., Sudduth, E., 2005. Standards for ecologically successful river restoration. Journal of Applied Ecology 42, 208-217.

Pierce, A.R., 2005. Sedimentation, hydrology, and bottomland hardwood forest succession in altered and unaltered tributaries of the Hatchie River, TN. Ph.D. dissertation. University of Tennessee, Knoxville, TN.

Pierce, A.R., King, S.L., 2007. The influence of valley plugs in channelized streams on floodplain sedimentation dynamics over the last century. Wetlands 27, 631-643.

Pizzuto, J.E., 1987. Sediment diffusion during overbank flows. Sedimentology 34, 301-317.
Ross, K.M., Hupp, C.R., Howard, A.D., 2004. Sedimentation in floodplains of selected tributaries of the Chesapeake Bay. In: Bennett, S., Simon, A. (Eds.), Riparian Vegetation and Fluvial Geomorphology. American Geophysical Union Water Science and Application Series, vol. 8, pp. 187-208. Washington, DC.

SAS Institute Inc., 2004. SAS Version 9.1. Cary, NC, USA.

Saucier, R.T., 1994. Geomorphology and Quaternary Geologic History of the Lower Mississippi Valley, vol. 1. U.S. Army Corps of Engineers, Vicksburg, MS.

Schumm, S.A., Harvey, M.D., Watson, C.C., 1984. Incised channels: morphology, dynamics, and control. Water Resources Publications, Littleton, Colorado.

Shankman, D., 1993. Channel migration and vegetation patterns in the southeastern Coastal Plain. Conservation Biology 7, 176-183.

Shankman, D., 1996. Stream channelization and changing vegetation patterns in the U.S. coastal plain. Geographical Review 86, 216-232.

Simon, A., 1989. The discharge of sediment in channelized alluvial streams. Water Resource Bulletin 25, 1177-1188.

Simon, A., 1994. Gradation Processes and Channel Evolution in Modified West Tennessee Streams: Process, Response, and Form. Professional Paper 1470. U.S. Geological Survey, Washington, DC.

Simon, A., Hupp, C.R., 1987. Geomorphic and vegetative recovery processes along modified Tennessee streams: an interdisciplinary approach to disturbed fluvial systems. Proc. Int. Symp. Forest Hydrology and Watershed Management. International Association of Scientific Hydrology, Vancouver, Canada, pp. 251-262.

Simon, A., Hupp, C.R., 1992. Geomorphic and Vegetative Recovery Processes Along Modified Stream Channels of West Tennessee. U.S. Geological Survey, Nashville, TN, USA.

Sokal, R.R., Rohlf, F.J., 1995. Biometry: The Principles and Practice of Statistics in Biological Research, 3rd Ed. W.H. Freeman and Company, New York.

Steiger, J., Gurnell, A.M., Goodson, J.M., 2003. Quantifying and characterizing contemporary riparian sedimentation. River Research and Applications 19, 335-352.

Thein, S.S., 1979. A flow diagram for teaching texture-by-feel analysis. Journal of Agronomic Education 40, 54-55.

Turner, R.E., Forsythe, S.W., Craig, N.J., 1981. Bottomland hardwood forest land resources of the southeastern U.S. In: Clark, J.R., Benforado, J. (Eds.), Wetlands of Bottomland Hardwood Forests: Proceedings of a Workshop on Bottomland Hardwood Forest Wetlands of the Southeastern U.S. Elsevier Science Publishing Company, NY, pp. 13-43.

U.S. Department of Agriculture (USDA), 1970. Hatchie River Basin Survey Report, Tennessee and Mississippi. USDA Soil Conservation Service, Washington, DC.

U.S. Department of Agriculture (USDA), 1986. Sediment Transport Analysis Report, Hatchie River Basin Special Study, Tennessee and Mississippi. USDA Soil Conservation Service, Washington, DC.

Walling, D.E., He, Q., 1998. The spatial variability of overbank sedimentation on river floodplains. Geomorphology 24, 209-223.

Walling, D.E., Owens, P.N., Leeks, G.J.L., 1998. Erratum to "The characteristics of overbank deposits associated with a major flood event in the catchment of the River Ouse, Yorkshire, UK". Catena 32, 309-331.

Ward, J.V., Tockner, K., 2001. Biodiversity: towards a unifying theme for river ecology. Freshwater Biology 46, 807-819.

Wyzga, B., 2001. Impact of the channelization-induced incision of the Skawa and Wisloka Rivers, Southern Poland, on the conditions of overbank deposition. Regulated Rivers: Research \& Management 17, 85-100. 